\title{
Personnel Policy in Terms of Sustainable Development of the Region
}

\author{
V. B. Dzobelova \\ North Ossetian State University after K. L. Khetagurov \\ Vladikavkaz, Russia \\ dzobelova@mail.ru
}

\author{
A. S. Yadati \\ North Ossetian State University after K. L. Khetagurov \\ Vladikavkaz, Russia \\ asuadati@nosu-team.ru
}

\begin{abstract}
Today, one of the most important tasks in the Russian Federation is an acceleration of the economic development pace, the introduction of promising innovative projects in all spheres of production and services. In this regard, the need for highly qualified specialists is growing. It is impossible without continuous improvement of the system of education and quality its improvement. The article discusses relevant issues of highly qualified personnel training for the solution of problems in accordance with the socio-economic priorities of the development of North Ossetia-Alania. The role of regional science in terms of training perspective highly qualified personnel for the branches of the regional economy is shown. The main directions for improving the processes of training within the educational space and the innovation system of the republic are identified. The problem of personnel training for high-tech industries is one of the most relevant problems for modern socioeconomic systems of any scale: from continuing education programs for industrial and production personnel of individual enterprises to strategies and training programs for personnel in regions and the state as a whole.
\end{abstract}

Keywords - innovation; personnel training;, regional economy; educational organizations; practice; investment

\section{INTRODUCTION}

In the context of globalization processes, in Russia the main strategic goal of national security providing is to ensure sustainable economic growth, the achievement of food security, creation of the necessary conditions for scientific and technological development, etc. All that will allow standing against domestic and external threats beforehand.

The development efficiency of modern high-tech industries of enterprises in various sectors of the economy depends directly on the quantitative and qualitative parameters of training in educational institutions at different levels. [6] In the long-term perspective, investments in the training and advanced training of high-tech personnel are strategically more important for the economic systems of modern industrialized regions compared with investments in innovative fixed funds and technologies.

In particular, in the opinion of A. A. Rabtsevich, one of the most general indicators that make it possible to assess the focus of the educational system of a certain level of personnel training for high-tech industries is the share of technical graduates in the total number of graduates of organizations of higher professional and secondary specialized education [4].

\section{METHODOLOGY}

North Ossetia is a multinational outpost of the state system in the center of the multimillion Caucasus, which has a cultural and historical foundation with rich nature and a high potential for the development of culture, education, healthcare, agriculture, industry, tourism and creative industries.

Further development of the region's economy depends on clearly defined goals, formed tasks, determination of targets and evaluation of the effectiveness of strategic development documents. So, in the Strategy of socio-economic development of the republic until 2030, the following priorities for the further development are defined: development of leading industries; agribusiness development; development of the sector of innovative industries (industry, information technology, biotechnology); infrastructure development (road network, energy).

As it is known, achieving strategic development goals for each of the identified priorities depends on the availability of qualified personnel. [7]

Young people are the main innovative potential of society and one of the most vulnerable groups in the labor market due to their age, socio-psychological and professional characteristics. The level of youth unemployment depends on many factors: the level of development of the region, its economic potential, the characteristics of the demographic situation, and the training system.

In 2018 , over 4,000 people were recognized as unemployed in North Ossetia-Alania. To reduce youth unemployment, a set of specific measures to regulate the sphere of employment have been developed and implemented. Last year, Employment Promotion Program for 2014-2024 and the Program for Additional Measures to Reduce Tension in the Labor Market in 2018 worked in the Republic of North Ossetia-Alania. The programs included a combination of long- and short-term measures, the purpose of which is an achievement of effective, optimal employment of the working population in the region. The efforts were aimed not only at the unemployed people but also at the employees of organizations, including those who were threatened with dismissal. This means that work on 
workforce quality improvement and preservation of jobs is underway.

In 2018, the Employment Service sent 219 graduates of institutions of higher and secondary vocational education for an internship to gain experience for further employment in organizations experiencing a need for personnel. Graduates of higher professional education - 87 people, secondary - 46 people, under the guidance of 118 mentors among them.

The list of specialties for which the internship is organized: architect, lawyer, economist, accountant, computer center technician, dentist, public relations specialist, manager, machine operator.

By the end of the Program, 47\% of the planned number of internships were employed. The number of citizens aged 14 to 29 years old received state services for vocational guidance (4.200 people), psychological support (610 people) and social adaptation (637 people).

In the Republic of North Ossetia-Alania, North Ossetian State University after K. L. Khetagurov (NOSU) is one of the oldest educational and scientific complexes of the North Caucasus Federal District. In 2017, NOSU won the competition of the priority project of the Ministry of Education and Science of Russia "Universities as centers of the space for creating innovation" and received the status of a university center for innovative, technological and social development of the region.

The rapid development of information and communication technologies and the widespread use of the Internet have led to a qualitative change in the educational technologies used in the world. The most popular model is the blended learning model. Along with full-time education, it widely uses electronic teaching aids: online courses, interactive workshops and laboratory work, computer modelling tools and simulators.

Modern Russian universities are gradually becoming centers of innovation, creation of new technologies and new sectors of the economy and the formation of a high-quality social environment in their region. Universities create new educational programs, apply new standards in teaching and use new technologies, launch joint scientific and technological projects, carry out research and development. As a result, the quality of education in the country is growing, the professional level of personnel is improving. All of that is a prerequisite for the successful modernization of the country's economy.

The key task of North Ossetian State University is the solution of applied research problems in the interests of the region and the implementation of research results in the economy and social sphere of the Republic of North OssetiaAlania. Priority areas of efforts are identified, based on an analysis of the potential, competitive advantages and strategic development goals of the Republic of North Ossetia-Alania until 2030.

The development strategy of North Ossetian State University, implemented with the help of the Roadmap, involves the implementation of a system of measures aimed at reforming the educational, research and international components of the university. The university competitiveness development program has made it possible to improve qualitatively cooperation with foreign universities and companies, which as a result allows the student to participate in scientific and educational projects around the world.

The education of a specialist and the realization of his mental and creative potential cannot always take place within the framework of the university. International cooperation with universities in the world is a kind of accelerator in the educational process; it also expands the boundaries of knowledge. Such cooperation develops the student professionally; gives a huge amount of opportunities to achieve goals; opens up many doors. The involvement of students of Russian educational institutions into the international community will provide an opportunity to withstand global challenges for graduates, increasing the level of educational mobility, competence and competitiveness. International cooperation between universities is a kind of catalyst in the process of education as a university as a whole, and the student individually. Note that at the end of the training process, the graduate enters the market of opportunities in search of employment. And it is beneficial for the employer to have among its employees those who, in addition to the main characteristics, have a wide breadth of views, innovative thinking, which is acquired through the experience exchange. For universities, international activity is of advantage in terms of expanding contacts, friendships, improving the quality of education in Russia, creating an image as a research center, increasing its relevance and universality for future applicants.

Like all Russian universities, North Ossetian State University, participating in international rankings, is interested in cooperation with foreign universities. Such cooperation allows increasing the number of summer and winter schools, attracting foreign students, which leads to an increase in the university budget and its positive perception by foreign companies. As a result, it becomes possible to graduate students, who are in demand for foreign labor markets. The student's interaction, both with Russian teachers and with foreign ones, allows forming a specialist who is ready for communication at different levels.

\section{RESULTS}

As part of the implementation of strategic partnership work programs, NOSU developed and carried out a set of joint activities in the form of scientific seminars in which participants present their projects, plan joint activities and undergo short-term intensive internships in the advanced laboratories of partner universities. The results of internships are agreements aimed at fulfilling efficiency indicators. The internship plan includes such events as preparing joint publications in SCOPUS, coordinating courses for inviting professors from partner universities, preparing applications for joint projects and attracting foreign students.

The development and implementation of international network of educational programs is an important tool for the internationalization of the university and increase its competitiveness in the global market for educational services, as it provides important advantages for the university, expressed in the development of the internationalization of the 
university; improving the quality of education; increasing the competence of teachers; attracting additional financial extrabudgetary funds to the university's budget.

The project "Personnel training for the education system", implemented by the Ministry of Education and Science of the Republic of North Ossetia-Alania since 2018, is aimed at attracting young teachers and developing human resources.

The project "Personnel training for the education system", approved by the order of the Ministry of Education and Science of the Republic of North Ossetia-Alania dated December 14, 2018 No. 1108, is aimed at implementation of a training system for the education system of the republic.

Within the framework of the project, systematic work was organized to develop continuously the professional skills of the education system employees, the content of continuing education programs is being substantially updated.

The basis of the project is the formation of conditions (system) for the continuous and systematic training of teachers, including through the use of new forms of career guidance, modern digital technologies, the formation and participation in professional associations and competitions, experience exchange and best practices, attracting employers to advanced training of teachers, including the forms of internships, the introduction of an effective mentoring system.

The project is aimed at improving the social status of teachers and educators, which will become an additional incentive for attracting young and ambitious specialists, improving the quality of education in general. The project implementation period is 2019-2024. As a result, a system of training young specialists and developing human resources will be created.

The activities of the regional project "Personnel training for the education system" are being implemented by stages. The work on the creation of a system, that will form personnel for education, has been carrying out by the Ministry of Education of the Republic for several years already.

Agency for Strategic Initiatives has developed the project "Personnel of the Future for the Regions", and plans to implement it in 2019-2020 in 23 constituent entities of the Russian Federation. A project under this name starts in the Republic of North Ossetia-Alania. This is not a platform exclusively for excellent students or public figures, but it is a platform for convinced patriots, which are sure of their possibility to change something around.

The project is aimed at the formation and development of leadership teams from active, ambitious and caring students who are able and willing to join to the design and implementation of social and economic projects important for their region.

There will be formed leadership teams consist of talented students from 14 to 17 years old. The teams will work under the guidance of mentors and tutors.

Participation in the project will give children the opportunity for social and professional attempts in various sectors of the economy and social sphere, regional and municipal government at key enterprises of the republic.

Today, despite their young age, children can think critically and can objectively evaluate the surrounding realities. This is a completely different generation, capable of radically different decisions, and the project is aimed at an influx of fresh ideas and forces. Specialists and experts from various departments of the Republic of North Ossetia-Alania are ready to supervise the project participants, nurturing personnel for North Ossetia. The initiative will be implemented in several priority areas for the region: tourism and recreation, the development of energy, industrial, transport, logistics and agro-industrial complexes, the production of building materials, medicine, education, IT technology and the socio-cultural sphere.

Moreover, the regional initiative "Personnel of the Future for the Region", solving its tasks, will help in the implementation of several federal programs of the national project "Education": "The success of every child", "Digital educational environment" and "Social activity". Indeed, it will become a productive mechanism of career guidance. It is worth paying attention to the result of a survey conducted by the NAFI analytical center last year, according to which more than a half of Russians say that the school didn't help them decide on their future profession. Then what motivated admission and labor activity can we talk about? And thanks to the project children will have the opportunity of professional attempts in various sectors of the economy and social sphere, regional and municipal management at key enterprises of the republic, as well as internships in production.

High schoolers will have open access to a digital educational platform where they will take online courses on leadership, project management, self-presentation skills, and creative thinking. They will meet new friends who may become their future partners in some projects.

Each participant will have the opportunity to implement their educational program, as well as the chance to take an internship at enterprises of North Ossetia. The initiative will end with the defence of team projects, the winners of which will be able to realize their ideas.

Assistance in the formation of an individual educational program for the most motivated and successful participants in the project will continue after its completion. Thus, in addition to viable projects that are designed to solve real problems in the socio-economic sphere of North Ossetia, in 2020 the republic should receive a certain register of promising personnel. How effective this initiative is one can see by the example of 7 pilot regions, where it was launched in April last year.

\section{CONCLUSION}

Today an improvement of personnel training and the formation of human potential for most countries are priority tasks. The quality of education in the country is growing, and the professional level of personnel is improving. The Russian Ministry of Education and Science is making great efforts to increase competitiveness in the global market for Russian education in general, as well as for individual universities. 
The integration of domestic science in the global processes of scientific and technological development will increase the efficiency of Russia's participation in the international division of labor in the scientific and technical field; promotion of Russian scientific developments on the world market; increasing the attractiveness of national research facilities, research programs and projects for foreign investors. All this contributes to a qualitative change in Russian educational and industrial institutions, the development of the economy of the Russian Federation, the involvement of scientists. In other words, it contributes an increase to the level of development of the entire state and citizens individually. While improving ourselves, we are developing Russia and the whole world.

\section{REFERENCES}

[1] Buryak V.V. Digital economy: breakthrough technologies in education. Innovacionnaya nauka [Innovative science], 2018, no. 7-8, pp. 55-59. (in Russian)

[2] Vagurina I.V. Problems of introduction of digital technologies in education. V sbornike: Transprofessionalizm kak prediktor social'noprofessional'noj mobil'nosti molodezhi Materialy Vserossijskoj (s mezhdunarodnym uchastiem) nauchno-prakticheskoj konferencii. Pod nauchnoj redakciej E.F. Zeera, V.S. Tret'yakovoj. [In the collection: Transprofessional as a predictor of socio-professional mobility of the youth Materials of all-Russian (with international participation) scientific-practical conference. Under the editorship of E. F. Zeera, V. S. Tretyakova]. 2019, pp. 340-342. (in Russian)

[3] Kotova L.R. Influence of digital technologies on education. V sbornike: Vzglyad pokoleniya XXI veka na budushchee cifrovoj ekonomiki sbornik statej prepodavatelej IX Mezhdunarodnoj nauchno-prakticheskoj konferencii "Sovremennaya ekonomika: koncepcii $i$ modeli innovacionnogo razvitiya" [In the collection: view of the XXI century generation on the future of digital economy collection of articles by teachers of the IX International scientific and practical conference "Modern economy: concepts and models of innovative development"]. 2018, pp. 183-186. (in Russian)
[4] Rabtsevich A.A. Innovative characteristics of labor market entities. Analysis and main directions of formation. M .: Infra-M, 2018, pp.152 (in Russian)

[5] Filatova O.N., Krupa V.V., Bystrova N.V. Professional education in the strategy of digital technologies development. Problemy sovremennogo pedagogicheskogo obrazovaniya [Problems of modern pedagogical education]. 2018, no. 61-2, pp. 200-202. (in Russian)

[6] Dzobelova V.B. New Ways of Qualified Staff Training by the Example of the Republic of North Ossetia-Alania. Proceedings of 2018 17th Russian Scientific and Practical Conference on Planning and Teaching Engineering Staff for the Industrial and Economic Complex of the Region, PTES 2018, pp. 23-28.

[7] Dzobelova V.B., Olisaeva A.V. Staffing Needs in the Regional Economy under the Modern Conditions of Labor Market. Proceedings of 2018 17th Russian Scientific and Practical Conference on Planning and Teaching Engineering Staff for the Industrial and Economic Complex of the Region, PTES 2018, pp. 185-188.

[8] Dzobelova V.B., Olisaeva A.V. Analysis of innovative development of the NCFD regions in Russia. IDIMT 2018: Strategic Modeling in Management, Economy and Society - 26th Interdisciplinary Information Management Talks, 2018, pp. 473-479.

[9] Olisaeva A.V., Dzobelova V.D., Yablochnikov S.L., Cherkasova O., Davletbayeva N. Formation and development of the digital economy in modern conditions -development within the framework of industry 4.0 In the collection: IDIMT-2019. Innovation and Transformation in a Digital World TRAUNER Druck GmbH \& Co KG, Linz, 2019, pp. 8388.

[10] Rysin Y.S., Terekhov A.N., Yablochnikov S.L., Ievlev O.P., Dzobelova V.B. On the Issue of Speaker's Identification in Communication Networks and Terminal Equipment of Onboard System 2019 Systems of Signals Generating and Processing in the Field of on Board Communications, SOSG, 2019.

[11] Yablochnikov S.L., Yablochnikova I.O., Vidov S.V., Kuptsov M.I., Olisaeva A.V. The Aspects of Modeling Information Processes Realized in Complex Telecommunication Systems. In the collection: Wave Electronics and its Application in Information and Telecommunication Systems, WECONF 2018, pp. 8604360. 